\title{
Inclusive environmental disclosure practices and firm performance:
}

\section{The role of Green Supply Chain Management}

Annachiara Longoni, (ESADE Business School, Ramon Llull University, Barcelona, Spain)

Raffaella Cagliano, (School of Management, Politecnico di Milano, Milan, Italy)

Article published in International Journal of Operations and Production Management

Please cite as: Longoni, A., \& Cagliano, R. (2018). Inclusive environmental disclosure practices and firm performance: the role of green supply chain management. International Journal of Operations \& Production Management, 38(9), 1815-1835.

https://doi.org/10.1108/IJOPM-12-2016-0728 


\title{
Inclusive environmental disclosure practices and firm performance: \\ The role of Green Supply Chain Management
}

\begin{abstract}
Purpose: Little empirical work has been done on the effects of inclusive environmental disclosure and green supply chain management on firm outcomes. The literature on environmental disclosure suggests that it is a useful practice to improve a firm's reputation and its financial performance and also to establish a dialogue with stakeholders improving environmental performance. Recent conceptual contributions in the supply chain management literature state that stakeholder expectations and informational needs increasingly concern firm supply chains. Thus, we propose that positive effects of inclusive environmental disclosure practices are enhanced in presence of green supply chain management practices.

Methodology: To test these relationships it was used a combination of primary data on environmental disclosure practices, green supply chain management practices and environmental performance, and secondary data on financial performance. A series of hierarchical regression models were performed to test the disclosure-outcome relationships and the moderation of green supply chain management practices.

Findings: Results provide empirical support for the impact of inclusive environmental disclosure practices on financial performance but no support for the impact on environmental performance. Specifically, the more inclusive the environmental disclosure practices the greater and positive is the impact on financial performance in presence of green supply chain management practices.
\end{abstract}


Originality: This study provides empirical evidence of the joint effects of inclusive environmental disclosure and green supply chain management practices on environmental and financial performance. Doing so, it reinforces the recent conceptual foundation that firms should align and leverage on supply chain management for disclosure practice effectiveness.

Keywords: stakeholders, environmental disclosure, green supply chain management

\section{Introduction}

Environmental disclosure is growing in importance due to the increased demand for environmental performance information by multiple stakeholders (Dawkins and Fraas, 2011; AlTuwaijri et al., 2004). Environmental disclosures practices concern information sharing with a variety of stakeholders about environmental pollution and natural resource consumption performance (Plumlee et al., 2015). The effectiveness of such practices to improve a firm's financial and environmental performance has been widely debated in the accounting literature and more recently in the supply chain management literature. The literature on environmental disclosure practices has proposed that they offer a way to legitimize a firms' reputation and image and thus useful to improve its financial performance (Qiu et al., 2016). Environmental disclosure practices have also been associated to socially responsible behaviors to improve a firm's sustainable performance (Gelb and Strawser, 2001). More recently, their effectiveness in leading to environmental and/or financial outcomes has been proposed to dependent on the type of stakeholders addressed that might advocate for different outcomes (Khan et al., 2016), for example economic partners focusing on financial performance or stakeholders representatives focusing on specific needs. Further, it is well accepted that potential advantages can be achieved 
where there is firms' credibility with specific stakeholders, meaning that management actions align with their expectations (Freeman, 1984).

In this sense, given the growing interest of stakeholders on how a firm is managing its supply chain, Green Supply Chain Management (GSCM) practices have been proposed to answer stakeholder needs and improve environmental performance. GSCM practices are often cited in environmental disclosure practices to show that actual actions are taken by the organization to improve environmental performance (Tate et al., 2010; Marshall et al., 2016). The initial focus of green practices on internal operations activities (i.e., production) to reduce pollution and material consumption (Klassen and Whybark, 1999) has broadened into a stronger external orientation including the adoption of green practices upstream and downstream in the supply chain (Pagell and Wu, 2009).

Contributing to the debate about the effectiveness of environmental disclosure practices and sustainable supply chain management practices, this paper seeks to make a two-fold contribution. First, we examine the impact of environmental disclosure practices on financial and environmental performance by testing two environmental disclosure models related to the level of inclusivity, meaning the degree to which a variety of diverse stakeholder groups are addressed in disclosure practices. In this way, we empirically respond to the recent calls for investigating how addressing different sets of stakeholders may influence the effectiveness of environmental disclosure practices and performance achievement (Gualandris et al., 2016; Khan et al., 2016). Second, in this study we provide empirical evidence about the effectiveness of different environmental disclosure practices in presence of the actual organizational practices implemented by the firm, such as GSCM. Thus, we empirically test the role of GSCM practices as a way to align with stakeholder needs and enhance environmental disclosure effectiveness. 
In the remainder of the paper we will review the current research on inclusive environmental disclosure and GSCM practices, develop hypotheses about the proposed relationships, and present and discuss the results of hypothesis testing.

\section{Theoretical background}

The challenge to include stakeholders in the management of organizations has grown significantly over the last ten years (Manetti and Toccafondi, 2011; Dawkins and Fraas, 2011). Initially, stakeholder-oriented literature referred to stakeholder management, meaning the management of expectations of parties influencing and being influenced by firm outcomes (Freeman, 1984). Then it moved the attention toward stakeholder engagement, meaning the involvement of stakeholders in decision-making processes, including them in the organization's management, sharing information, using dialog, and creating a reciprocal model of responsibility (Svendsen, 1998). It is not surprising that in such a setting, the importance for firms to address the informational needs of multiple stakeholders has gained increasing relevance (Gualandris et al., 2016). To face such needs, a growing number of organizations has begun to disclose information to more and more stakeholders in relation to sustainability outcomes, especially environmental performance (Dawkins and Fraas, 2011; Al-Tuwaijri et al., 2004). In most cases, environmental disclosure practices, meaning sharing environmental performance information (e.g., pollutant emission and natural resource consumption) with a variety of stakeholders, are voluntary actions that is not required by law or code of practice (e.g., annual reports and proxy statements) or go beyond what is required, and are useful for stakeholder decision-making (Dawkins and Fraas, 2011). Standards for environmental disclosure practices have been discussed by several non-profit associations (e.g., the GRI (Global Reporting Initiative 
(GRI), the Federation des Experts Comptables Europeens (FEE), the International Federation of Accountants (IFAC)). However, there are wide variations in environmental disclosure practices across companies (Kolk, 2003; Patten, 2002; Russo and Fouts, 1997).

Given the growing relevance of this phenomenon, academic literature has increasingly investigated inclusive environmental disclosure practices mainly in relation to the reasons driving companies to disclose information. Thus, the relationship between environmental disclosure practices and performance has been mainly investigated considering environmental performance as a driver of disclosure (e.g., Patten, 2002; Al-Tuwaijri et al., 2004).

In this paper we consider the other side of the coin and investigate the impact of inclusive environmental disclosure practices on outcomes achievement. Different impacts of inclusive environmental disclosure practices are proposed in the literature: On one side, environmental disclosure practices can improve a firm's reputation and thus its economic and financial outcomes (Spingett, 2003); on the other side, through environmental disclosure practices a firm can establish a dialogue with stakeholders so that environmental values are made explicit and taken into consideration in an organization's decision making process, thus improving its environmental impacts (Al-Tuwaijri et al., 2004; Clarkson et al., 2008; Cormier et al., 2009, 2011; Patten, 2002). In case of positive impacts on both environmental and financial performance, environmental disclosure practices could serve as proof for the sustainability business case.

However, recent studies urge to understand how the effectiveness of environmental disclosure is related to the different types of addressed stakeholders and the consistency with the actual organizational practices. Specifically, supply chain management is defined as "the management of a network of relationships within a firm and between interdependent 
organizations and business units [...] that facilitate the forward and reverse flow of materials, services, finances and information from the original producer to final customer with the benefits of adding value, maximizing profitability through efficiencies, and achieving customer satisfaction” (Stock and Boyer, 2009, p. 691). These activities have a primary impact on the environment, making the deployment of environmental capabilities in such context a crucial issue (Kleindorfer et al., 2005). Thus, it is not surprising that firms implement GSCM practices to answer stakeholders' environmental needs and requests. In the supply chain management domain, environmental principles have been integrated first in internal operations processes (e.g., production processes) (Sarkis and Rasheed, 1995). This was done mainly through the adoption of reactive environmental management practices (e.g., pollution control technologies) and then moving toward the adoption of proactive and preventive practices (e.g., pollution prevention technologies) (Klassen and Whybark, 1999). More recently, focal companies have been considered accountable not only for their internal operations processes but also for their suppliers, thus extending environmental management activities outside company boarders (Krause et al., 2009). Accordingly, GSCM practices are implemented across a company’s supply-chain and regard internal and external processes (Gimenez et al., 2012; Wolf, 2014):

i) Internal GSCM practices concern the reduction of consumption of raw resources, production of waste, use of toxic materials, and toxic emissions in internal operational processes (i.e., product development and production) (Gimenez et al., 2012; Green et al., 2012; Sarkis, 2012).

ii) External GSCM practices concern the reduction of the volume of purchased items and the use of hazardous materials, minimization of unnecessary packaging and increased use of recycled/recyclable materials in external operational processes (i.e., supplier selection and collaboration) (Gimenez et al., 2012; Gimenez and Sierra, 2013; Zsidisin and Siferd, 2001). 
In what follows we will review and assess the literature linking environmental disclosure practices to organizational performance and to green SCM practices to develop our hypotheses about the proposed relationships.

\subsection{Hypotheses development}

Inclusive environmental disclosure practices and performance achievement

Greater access to environmental information through disclosure practices to a wider set of stakeholders is viewed as an essential part of increasing transparency surrounding corporate activity and its consequences for stakeholders (Brown and Fraser, 2006). Disclosing environmental information with stakeholders may be a crucial tool to start a dialogue aiming to take into account stakeholder needs and take decisions accordingly (Brown and Fraser, 2006). Additionally, from a stakeholder perspective responsiveness to the multiplicity of constituencies interested in corporate performance requires different approaches (Gualandris et al., 2016). Thus, companies are increasingly disclosing environmental information through publishing 'triple bottom line', 'sustainable development' and CSR (Corporate Social Responsibility) reports (Deegan and Gordon, 1996; Morhardt et al., 2002; Kolk, 2003) addressing different sets of stakeholders ranging from shareholders to governments, NGOs, unions, customers and others (Solomon and Lewis, 2002). More broadly, the academic literature suggests that environmental disclosure would benefit from greater stakeholder inclusivity (Gray, 2000; Owen et al., 2000, 2001), meaning the degree to which a variety of diverse stakeholders groups is addressed (Ball et al., 2000; Owen et al., 2001; Reed, 2008). From a practical perspective, standards and reporting frameworks like ISO 26000, AA1000S, SA8000 and GRI also stress the importance of including multiple stakeholders (Manetti and Toccafondi, 2011). 
On one side, sharing information about environmental performance with a firm’s stakeholders is proposed as a way to improve its success, through addressing the needs of a broad set of stakeholders (Freeman, 1984). Accordingly, several studies advance that environmental disclosure can impact financial performance through a better firm's reputation and a broader impact can be achieved if different stakeholder types are addressed. For example, Cerin's (2002) case study shows that firms issue CSR reports as a marketing tool to enhance brand image among stakeholders. Hart (1995, p. 999) states that effective communication on environmental performance 'reinforce and differentiate a firm's position through the positive effects of a good reputation.' A firm's reputation is suggested to be potentially valued also by investors (Armitage and Marston, 2008; Hart, 1995) and may increase customer loyalty and firm sales (Qui et al., 2016). Companies seek to enhance their image in order to create a positive reputation that may also correlate to higher long-run financial performance (Fombrun and Shanley, 1990; Porter and Van Linde, 1995). Overall, this might contribute to a firm's financial performance, through a differentiation advantage compared to its peers. Thus, we formulate the following hypothesis:

H1. Inclusive environmental disclosure practices have a positive impact on a firm's financial performance.

On the other side, stakeholder management and its related tools, such as environmental disclosure practices, should push the management to pursue actions that are optimal for a broad class of stakeholders rather than those that serve only to maximize shareholder interests (Freeman, 1984). In this sense, it might mean that stakeholder disclosure is a socially responsible behavior to address multiple stakeholder needs and improve sustainability performance, such as 
environmental sustainability. In this sense, the literature promotes more open and participatory forms of corporate governance, where stakeholders have more voice in the organization's decisions that affect them, might positive impact sustainability performance (Gray et al., 1995; Gray and Milne, 2002; Kelly, 2001). Inclusive environmental disclosure practices, meaning dialoguing with a broad set of stakeholders through environmental information sharing, is viewed as a vital pre-requisite for informed participation (Brown, 2000, pp. 54-55). The utility of information sharing practices is not in its representation of 'infallible truth' but in making visible environmental values and priorities that become inputs to wider democratic processes of dialogue and decision making with stakeholders (Boyce, 2000, p. 53), with the aim to improve environmental performance. Accordingly, we formulate our second hypothesis:

H2. Inclusive environmental disclosure practices have a positive impact on environmental performance.

The moderating role of green supply chain management practices

Concerns among academics and practitioners are emerging about how statements in disclosure practices compare with the actual firm commitment of addressing sustainability issues. For example, Kolk (2003) show the difficulties to determine whether an organization was actually implementing the strategies and management actions or merely reporting to conciliate stakeholders. Similarly, Cerin (2002) identifies discrepancies between the actual actions of the reporting firms and what actions are reported in CSR reports and annual reports. Recent contributions also show that stakeholders are able to identify this possible mis-matches between 
environmental disclosure practices and actual green practices within the firm (Cormier and Magnan, 2015).

Thus, we suggest that an imbalance between environmental information disclosed by firms and their actual operational practices may impact on disclosure-outcome relationships. This may preclude both the possibility to create a positive firm image - i.e., improving financial performance, and to establish a dialogue with stakeholders - i.e., improving environmental performance.

Prescriptions concerning green practices range within different organizational areas from core activities (i.e., operational processes) to support activities (i.e., human resource management) (Porter and Kramer, 2006). In many organizations, supply chain processes contribute to environmental sustainability more than any other organizational areas through production processes and a choice of suppliers, materials, technologies, manufacturing and transport modes (Carter and Rogers, 2008). Accordingly, among the different environmental information disclosed supply chain management-related aspects are gaining relevance and information about GSCM practices are common in disclosure initiatives (Tate et al., 2010).

Firms using disclosure practices to share information about environmental performance in their supply chain might pursue different strategies and yet achieve different outcomes. For example, Marshall et al. (2016) propose that firms can adopt two high disclosure strategies: Transparent and Distracting. The Transparent strategy is adopted by those firms highly disclosing information to their stakeholders and also assessing and managing their operations and supply chain activities, thus implementing green SCM practices. Instead, the Distracting strategy is adopted by those firms highly disclosing information but having limited knowledge and actions on their supply chain activities, thus with a limited adoption of green SCM practices. In 
this case, disclosing information confuses firm stakeholders and more disclosure does not mean better performance. Similarly, New (2015) recommends that research on sustainability should focus less on practices espoused by firms but more on the enacted practices to explain a firm's actual performance. Therefore, we suggest that environmental disclosure practices positively affect organizational performance in presence of GSCM practices, in line with the Transparent strategy proposed by Marshall et al. (2016). In this way, the adoption of GSCM practices will reduce the potential imbalance between expectations related to environmental information disclosed and firm actions and be an effective answer to stakeholders' needs, enhancing the disclosure-outcome relationship. These positive effects will be lacking in situations in line with the Distracting strategy proposed by Marshal et al. (2016) in which companies are disclosing environmental information but not adopting green organizational practices (i.e., green SCM practices). Thus, we posit that:

H3: The impact of inclusive environmental disclosure practices on (a) financial performance and (b) environmental performance is moderated by GSCM practices, with inclusive environmental disclosure practices having a stronger positive impact in organizations with high GSCM practices.

The research hypotheses can be summarized in the research model presented in Figure 1.

\section{Please insert Figure 1 about here}

\section{Methodology}

To test our research model we combine primary and secondary data sources. Primary data refer to inclusive environmental disclosure practices, GSCM practices and environmental performance and are drawn from a survey on sustainable supply chain management performed between 
September 2011 and July 2012 in the Italian food sector. The questionnaire from which primary data are drawn contains four sections: i) firm description; ii) sustainability strategy, sustainable supply chain management, and operations practices; iii) drivers, barriers, and disclosure initiatives; and iv) benefits and performance. The questionnaire was developed based on a literature review in the accounting and sustainable supply chain research fields and on previous case studies conducted by the authors of this paper. Moreover, external academics and firms were actively involved to verify content validity by means of a pre-test. The questionnaire was checked by academics with a background in accounting, supply chain management and sustainability research. They assessed the viability of the questionnaire and its consistency with the current literature, ultimately providing positive feedback. The questionnaire was then submitted to eight managers whose background corresponded with that of this survey's target respondent. These managers provided useful feedback as to item formulation and wording. Specifically, they highlighted the need to provide further detail on a number of concepts. In these cases, we added some examples to clarify the intended meaning. Data collection was performed through an e-mail survey after firms were first contacted by phone to introduce the research project. The target respondents were people in charge of sustainability development at the firm level, operations level, and supply chain level; hence the questionnaire was completed by the operations manager, supply chain manager, or the individual responsible for sustainability development in the firm.

Secondary data are related to financial performance of the organizations and covers a 6years period ranging from three years before to three years after primary data collection. Financial performance are drawn from the AIDA database containing information and balance sheets of all Italian firms, covering also the food sector. It is provided by Bureau van Dijk (BvD) 
and it is the Italian version of the Orbis database (http://orbis.bvdinfo.com). The combination of primary data on the organization's sustainability practices and performance and secondary data on objective financial performance provides an excellent opportunity to start assessing the relationship between inclusive environmental disclosure and corporate outcomes and its possible enablers.

\subsection{Sample}

The sample frame consisted of lists of 'Top Italian Food Producers’ and the Italian Association of Food Producers. Only food processors were included in the sample. The food industry is a useful context in which to analyse the impact of inclusive environmental disclosure initiatives, given the increasing attention toward responsible behaviours of food companies. The sample of firms participating in the survey was composed of 134 organizations. The overall response rate was $16.52 \%$. For this sample, we used data only from organizations that filled all the information needed for this research. Therefore, the sample was reduced to 110 firms. Table 1 illustrates the demographics of the sample in terms of firm size and type of respondent.

Table 1: Demographics of the sample

\begin{tabular}{lr}
\hline Characteristics & Sample $\%$ \\
\hline Size (number of employees) & \\
Under 10 & $4,5 \%$ \\
$10-49$ & $32 \%$ \\
$50-249$ & $50 \%$ \\
$250+$ & $13,5 \%$
\end{tabular}




\subsection{Measures}

In line with our research aims, the main constructs measured herein concern inclusive environmental disclosure, GSCM practices, environmental performance and financial performance.

Independent variables: Inclusive environmental disclosure practices

While the concept of environmental disclosure fits well into the literatures in accounting (e.g., Al-Tuwaijri et al., 2004; Clarkson et al., 2008) previous research has not developed clear metrics to measure different inclusive disclosure practices in relation to different stakeholders. To assess the degree of inclusive environmental disclosure practices, we identified multiple sets of stakeholders based on the stakeholder management literature (Freeman, 1984). Table 2 provides the list of items included in the survey to address environmental disclosure with different stakeholders.

Table 2: Environmental disclosure practice items

\begin{tabular}{lcc}
\hline Questionnaire item & Mean & $\begin{array}{c}\text { Standard } \\
\text { Deviation }\end{array}$ \\
\hline To what extent information about environmental sustainability performance have been disclosed to \\
the following stakeholders? [Specify: Not at all (1), A bit (2), Quite (3), A lot (4), Very much (5)] \\
Suppliers & 1.96 & 1.13 \\
Distributors & 2.09 & 1.14 \\
Final consumers & 2.10 & 1.09 \\
Customers & 2.50 & 1.19 \\
Shareholders & 2.53 & 1.33 \\
Employees/Unions & 2.42 & 1.20 \\
Industrial associations/NGOs & 1.92 & 1.04 \\
Local community & 1.95 & 1.02 \\
Mass media & 1.87 & 1.09 \\
National, European, International regulatory institutions & 1.88 & 1.12 \\
Banks & 1.94 & 1.14 \\
Scientific community/ Research institutions & 1.79 & 1.01 \\
\hline
\end{tabular}


Inclusive environmental disclosure practices refer to the degree to which a variety of diverse stakeholder groups are informed about a firms' environmental performance. To measure the degree of inclusive environmental disclosure practices, we analyzed firstly the distributions of items regarding environmental disclosure practices with different stakeholders. Next, we identified the degrees of inclusive environmental disclosure considering disclosure practices with different stakeholder groups. To do so, we used cluster analysis to identify patterns of adoption of environmental disclosure practices with different sets of stakeholders using items listed in Table 2. A two-step clustering procedure was used. An initial hierarchical clustering was performed on random subsamples to determine the number of clusters. The three clusters solution was determined to be the best one. Subsequently, we performed non-hierarchical clustering using the K-means cluster algorithm to generate the three clusters. Finally, we tested whether the efforts toward the sets of stakeholders considered were effectively discriminated across the three disclosure groups using one-way ANOVA; all F-statistics were highly significant $(\mathrm{p}<0.01)$. The results of the K-means cluster algorithm and the ANOVA are shown in Table 3. Based on the significantly different average values of environmental disclosure practices with different sets of stakeholders, the three clusters are interpreted as follows: no environmental disclosure practices, that refers to no or low environmental disclosure practices with stakeholder, primary stakeholder disclosure practices, that refers to medium levels of environmental disclosure practices with primary stakeholders, and extended stakeholder disclosure practices, that refers to high levels of environmental disclosure practices with primary and secondary stakeholders. Consequently, inclusive environmental disclosure practices are measured as a dummy variable representing the belonging to one of the three clusters. 
Table 3: Inclusive environmental disclosure practice clusters and ANOVA results

\begin{tabular}{|c|c|c|c|c|c|c|c|c|c|c|c|c|c|}
\hline & $\mathrm{N}$ & Suppliers & Distributors & $\begin{array}{c}\text { Final } \\
\text { consumers }\end{array}$ & Customers & Shareholders & $\begin{array}{c}\text { Employees } \\
\text { /Unions }\end{array}$ & $\begin{array}{c}\text { Local } \\
\text { community }\end{array}$ & $\begin{array}{c}\text { Industrial } \\
\text { associations/ } \\
\text { NGOs }\end{array}$ & $\begin{array}{l}\text { Mass } \\
\text { media }\end{array}$ & $\begin{array}{l}\text { Regulatory } \\
\text { institutions }\end{array}$ & Banks & $\begin{array}{l}\text { Scientific } \\
\text { community/ } \\
\text { Research } \\
\text { institutions }\end{array}$ \\
\hline \multirow{4}{*}{$\begin{array}{l}\text { No } \\
\text { environmental } \\
\text { disclosure } \\
\text { practices } \\
\text { Primary } \\
\text { stakeholder } \\
\text { disclosure } \\
\text { practices }\end{array}$} & \multirow[t]{2}{*}{36} & 1.00 & 1.03 & 1.03 & 1.28 & 1.36 & 1.36 & 1.06 & 1.14 & 1.06 & 1.06 & 1.06 & 1.00 \\
\hline & & 2,3 & 2,3 & 2,3 & 2,3 & 2,3 & 2,3 & 2,3 & 2,3 & 2,3 & 2,3 & 2,3 & 2,3 \\
\hline & \multirow[t]{2}{*}{48} & $\underline{2.13}$ & $\underline{2.15}$ & $\underline{2.17}$ & $\underline{2.73}$ & $\underline{2.69}$ & $\underline{2.54}$ & $\underline{2.02}$ & 1.92 & 1.73 & 1.83 & 1.94 & 1.71 \\
\hline & & 1,3 & 1,3 & 1,3 & 1,3 & 1,3 & 1,3 & 1,3 & 1,3 & 1,3 & 1,3 & 1,3 & 1,3 \\
\hline \multirow{3}{*}{$\begin{array}{l}\text { Extended } \\
\text { stakeholder } \\
\text { disclosure } \\
\text { practices } \\
\text { Total Mean }\end{array}$} & \multirow[t]{2}{*}{26} & $\underline{3.00}$ & $\underline{3.46}$ & $\underline{3.46}$ & $\underline{3.77}$ & $\underline{3.85}$ & $\underline{3.65}$ & $\underline{3.08}$ & $\underline{\mathbf{3 . 0 0}}$ & $\underline{3.27}$ & $\underline{3.12}$ & $\underline{3.15}$ & $\underline{3.04}$ \\
\hline & & 1,2 & 1,2 & 1,2 & 1,2 & 1,2 & 1,2 & 1,2 & 1,2 & 1,2 & 1,2 & 1,2 & 1,2 \\
\hline & 110 & 1.96 & 2.09 & 2.10 & 2.50 & 2.53 & 2.42 & 1.95 & 1.92 & 1.87 & 1.88 & 1.94 & 1.79 \\
\hline
\end{tabular}

Note: The bold and italic values in the first rows represent highest and lowest score, respectively, for each variable. Underline values represent values above sample mean.

Cluster differences have been assessed by means of a Scheffé post-hoc test with significance $<0.05$ and indicated in the second row (Cluster 1: No environmental disclosure practices, Cluster 2: Primary stakeholder disclosure practices, Cluster 3: Extended stakeholder disclosure practices) 


\section{Moderator variables: GSCM practices}

GSCM practices are related to environmental-oriented activities performed in the internal supply chain and along the supply chain processes. Two constructs are used to measure them: Internal GSCM practices, related to internal processes (i.e., production processes) and concern the efforts to reduce raw material, water and energy consumption reduction, and pollution emissions reduction (Sarkis et al., 2012); and external GSCM practices, related to supplier selection according to environmental principles and capabilities (Zhu et al., 2005 and 2012). To assess the level of internal and external GSCM practices, firms were asked to score on a Likert scale (from $1=$ not adopted to $5=$ extensively adopted) the efforts taken in related actions in the last three years. We conducted confirmatory factor analysis (CFA) to validate our measures and to confirm our proposed factor structure. Table 4 provides the full list of items related to internal and external GSCM practicesand CFA results. The two-factor CFA model proposed has acceptable fit statistics (RMSEA $=0.04, \mathrm{CFI}=0.99$ ). Specifically, the root mean square error of approximation RMSEA is below 0.05 and CFI is above 0.95 (Hu and Bentler, 1999), thus indicating convergent validity (Bollen, 1989). Furthermore, all factor loadings exceeded the value of 0.50 , and the p-values were all lower than 0.05 (see Table 3) (Vickery et al., 2003). Finally, factor loadings all exceeded twice the value of their associated standard error, which further indicates convergent validity (Flynn et al., 2010). To completely confirm the validity of the scales, we evaluated the discriminant validity of the model. Discriminant validity is evaluated by means of the average extracted variance (AVE). Fornell and Larcker (1981) recommend an average extracted variance higher than 0.50 , thus guaranteeing that more than $50 \%$ of the factor's variance is due to its indicators. As shown in Table 4, all the AVE values are higher than the minimum required value. Finally, Composite Reliability (CR) has been used to test for 
reliability. The CR values listed in Table 4 are all above the commonly accepted level of 0.70 , which indicates that reliability is relatively high. Based on the above analyses, the validity and reliability of our scales were established.

Table 4: Green supply chain management practices items and confirmatory factor analysis results

$\begin{array}{llllllll}\text { Construct } & \text { Questionnaire item } & \begin{array}{c}\text { Item } \\ \text { loading }\end{array} & \text { St. Error } & \begin{array}{c}\mathrm{p}^{-} \\ \text {value }\end{array} & \text { CR AVE } & \text { Mean } & \text { St. Dev. }\end{array}$

To what extent the following practices have been adopted in the manufacturing process by your company in the last 3 years? [Specify: Not at all (1), A bit (2), Quite (3), A lot (4), Very much (5)]

\begin{tabular}{|c|c|c|c|c|c|c|c|c|}
\hline Internal & Waste reduction practices & 0.83 & 0.04 & 0.00 & 0.89 & 0.67 & 3.35 & 0.96 \\
\hline \multirow{3}{*}{$\begin{array}{l}\text { GSCM } \\
\text { practices }\end{array}$} & Energy use reduction practices & 0.88 & 0.03 & 0.00 & & & & \\
\hline & Water use reduction practices & 0.82 & 0.04 & 0.00 & & & & \\
\hline & $\begin{array}{l}\text { Reduction of the emissions } \\
\text { practices }\end{array}$ & 0.74 & 0.05 & 0.00 & & & & \\
\hline \multirow[t]{5}{*}{$\begin{array}{l}\text { External } \\
\text { GSCM } \\
\text { practices }\end{array}$} & $\begin{array}{l}\text { Supplier selection based on } \\
\text { sustainability competences (e.g., } \\
\text { clean technologies, environmental } \\
\text { programmes) }\end{array}$ & 0.85 & 0.03 & 0.00 & 0.93 & 0.74 & 2.37 & 0.97 \\
\hline & $\begin{array}{l}\text { Supplier selection based on } \\
\text { current sustainability } \\
\text { performance }\end{array}$ & 0.90 & 0.02 & 0.00 & 0.90 & & & \\
\hline & $\begin{array}{l}\text { Supplier selection based on their } \\
\text { sustainability reputation }\end{array}$ & 0.90 & 0.02 & 0.00 & 0.90 & & & \\
\hline & $\begin{array}{l}\text { Supplier selection based on the } \\
\text { sustainability certifications }\end{array}$ & 0.78 & 0.04 & 0.00 & 0.78 & & & \\
\hline & $\begin{array}{l}\text { Supplier selection based on their } \\
\text { capability of developing } \\
\text { sustainable products }\end{array}$ & 0.86 & 0.03 & 0.00 & 0.86 & & & \\
\hline
\end{tabular}

Dependent variables: Financial performance and environmental performance

Financial performance is measured using financial performance compared to industrypeers. Specifically, the average of Return on Investment (ROI) in the three years after the survey compared to industry peers was used to predict a firm's financial performance. 
Environmental performance is measured via four items regarding material, energy and water usage and pollution emission formulated in line with the Kinder, Lydenberg and Domini (KLD) strength parameters for evaluating company environmental performance (Walls et al., 2012). To assess the level of environmental performance, firms were asked to score on a Likert scale (from $1=$ not at all to $5=$ very much) their level of achievement in the last three years. The reliability of this construct has been tested through a CFA model. Table 5 provides the full list of items related to environmental performance and CFA results. The one-factor model tested has acceptable fit statistics (CFI=1.00, RMSEA=0.00). Further all factor loadings exceeded the value of 0.50, and the p-values were all lower than 0.05 (see Table 5) (Vickery et al., 2003) and exceeded twice the value of their associated standard error, which indicates convergent validity (Flynn et al., 2010). Also in this case, discriminant validity is evaluated by means of the AVE and it is higher than the minimum required value; CR also shows a good reliability being above the commonly accepted level of 0.70 .

Table 5: Environmental performance items and confirmatory factor analysis results

\begin{tabular}{|c|c|c|c|c|c|c|c|}
\hline Questionnaire item & $\begin{array}{c}\text { Item } \\
\text { loading }\end{array}$ & St. Error & p-value & CR & AVE & Mean & St. Dev. \\
\hline \multicolumn{8}{|c|}{$\begin{array}{l}\text { To what extent the following performance have been achieved in the last } 3 \text { years? [Specify: Not at all (1), A bit } \\
\text { (2), Quite (3), A lot (4), Very much (5)] }\end{array}$} \\
\hline Material consumption & 0.75 & 0.05 & 0.00 & 0.86 & 0.61 & 3.44 & 0.80 \\
\hline Energy consumption & 0.77 & 0.05 & 0.00 & & & & \\
\hline Water consumption & 0.85 & 0.04 & 0.00 & & & & \\
\hline Pollution emission & 0.76 & 0.05 & 0.00 & & & & \\
\hline
\end{tabular}

\section{Control variables}

We included two control variables in the analysis: firm size and past financial performance. In this way, we controlled for possible impacts related to firm size — as the logarithm of the number 
of employees_-on outcome achievement because the size of the organization has been suggested to be related to the level of commitment toward environmental issues (Vachon, 2007). We controlled also for past financial performance, measured using the average of ROI in the three years before the survey compared to industry-peers to take into consideration the level of resources available at the firm level to deploy environmental commitment (Vachon, 2007) and its competitive position in the market.

\section{Results}

Test of Hypothesis 1 and 2: Inclusive environmental disclosure practice impacts

To test Hypothesis 1 and 2 we performed a hierarchical regression model for each outcome dimension studied (i.e., financial performance - to test Hypothesis 1 - and environmental performance - to test Hypothesis 2). Specifically, we included as independent variables in the regression analysis two dummy variables measuring different levels of inclusive environmental disclosure practices (i.e., primary stakeholder disclosure practices and extended stakeholder disclosure practices). Given that we aim to study the impact of inclusive environmental disclosure practices, the no environmental disclosure practices group is the reference group in the regression analysis and thus it is the dummy variable not included in the regression. For each outcome dimension we performed a hierarchical regression in two steps by introducing the control variables (i.e., past financial performance and firm size), followed by the environmental disclosure practices dummy variables.

Table 6 presents the results for each outcome dimension. In the financial performance model adding the environmental disclosure practices variables improved the explanatory power and the model is significant $(\mathrm{p}=0.00)$. Specifically, the extended stakeholder disclosure practices 
variable is significant $(\mathrm{p}=0.04)$ and has a positive coefficient meaning that the group of companies with extended stakeholder disclosure practices performs significantly better than the reference group (i.e., no environmental disclosure). Instead, the primary stakeholder disclosure practices variable is not significantly different from the reference case (i.e., no environmental disclosure $)(\mathrm{p}=0.29)$. Therefore, Hypothesis 1 suggesting a positive impact of inclusive environmental disclosure practices on financial performance is partially supported. Specifically, when environmental disclosure practices are limited and restricted to primary stakeholders, financial performance are on average not improved. Instead, when environmental disclosure practices are higher and include a wide range of stakeholders financial performance are on average significantly improved. On the other side, in the environmental performance model, inclusive environmental disclosure practices variables do not improve the explanatory power and the model is not significant ( $\mathrm{p}=0.58$ ), thus not supporting Hypothesis 2 .

Table 6: Regression models testing hypotheses 1 and 2

\begin{tabular}{|c|c|c|c|c|c|c|c|c|}
\hline & \multicolumn{4}{|c|}{ Financial performance } & \multicolumn{4}{|c|}{ Environmental performance } \\
\hline & \multicolumn{2}{|c|}{ Model 1} & \multicolumn{2}{|c|}{ Model 2} & \multicolumn{2}{|c|}{ Model 1} & \multicolumn{2}{|c|}{ Model 2} \\
\hline & Coefficient & Sig. & Coefficient & Sig. & Coefficien & Sig. & Coefficient & Sig. \\
\hline Intercept & -0.10 & 0.76 & -0.16 & 0.04 & $3.44 * * *$ & 0.00 & $3.44^{* * *}$ & 0.00 \\
\hline Past financial performance & $0.38 * * *$ & 0.00 & $0.35 * * *$ & 0.00 & -0.02 & 0.37 & -0.02 & 0.38 \\
\hline Firm size & 0.03 & 0.71 & -0.02 & 0.76 & 0.02 & 0.82 & -0.03 & 0.70 \\
\hline $\begin{array}{l}\text { Primary stakeholder disclosure } \\
\text { practices }\end{array}$ & & & 0.23 & 0.29 & & & 0.27 & 0.23 \\
\hline $\begin{array}{l}\text { Extended stakeholder disclosure } \\
\text { practices }\end{array}$ & & & $0.52^{* *}$ & 0.04 & & & 0.38 & 0.17 \\
\hline p-value & 0.00 & & 0.00 & & 0. & & 0.5 & \\
\hline Adjusted $\mathrm{R}^{2}$ & 0.21 & & 0.27 & & 0. & & $-0 .($ & \\
\hline
\end{tabular}

${ }^{+} \mathrm{p}<.10 * \mathrm{p}<0.05,{ }^{* *} \mathrm{p}<0.01,{ }^{* * *} \mathrm{p}<0.001$. 
Test of moderation hypothesis: The role of green supply chain management practices (Hypothesis 3)

Because we propose a moderation effect of GSCM practices, we followed the approach of Byrne (2006). We first tested for the direct effect using the entire sample, to address hypotheses 1 and 2, and then we tested for moderation by splitting the sample into high and low GSCM practices groups to address Hypothesis 3. We used the average level of GSCM practices to split the sample into two groups. Specifically, we repeated the procedure twice: one considering internal GSCM practices and one considering external GSCM practices.

Results concerning the financial and environmental performance models are shown respectively in Table 7 and Table 8 . Concerning financial performance, results show that significance and coefficients of inclusive environmental disclosure practice variables are higher in high internal GSCM and high external GSCM groups compared to low internal GSCM and low external GSCM groups. The significant difference between high and low groups has been also tested comparing coefficients across the two groups through a two-independent-sample t test (Keil et al., 2000), showing the equality of standard errors in the two sub-samples and thus the significance of the found differences. The two-independent-sample t test was performed in relation to both internal and external GSCM practices showing the reliability of regression results. Furthermore, in presence of high internal and external GSCM practices also the primary stakeholder variable is shown to be slightly significant (with $\mathrm{p}<=0.10$ ) and has a positive coefficient. This indicates that the impact of primary and extended stakeholder environmental disclosure practices to financial performance is significantly different for high vs. low GSCM groups as shown in Table 7. Specifically, there is a positive moderation effect. Thus, the results support Hypothesis 3a. 
Instead, concerning environmental performance results in Table 8 indicate that also considering GSCM practices as moderators, inclusive environmental disclosure practices do not significantly impact on environmental outcomes and the models are not significant (i.e., internal GSCM models: $\mathrm{p}=0.65$ and 0.89 ; external GSCM models: $\mathrm{p}=0.49$ and 0.73 ). Thus Hypothesis $3 \mathrm{~b}$ on the moderation effect of GSCM practices on the disclosure-environmental performance relationship is not supported.

Table 7: Regression models testing hypothesis 3a (financial performance)

\begin{tabular}{|c|c|c|c|c|c|c|c|c|}
\hline & \multicolumn{4}{|c|}{ Internal GSCM practices } & \multicolumn{4}{|c|}{ External GSCM practices } \\
\hline & \multicolumn{2}{|c|}{ High } & \multicolumn{2}{|l|}{ Low } & \multicolumn{2}{|c|}{ High } & \multicolumn{2}{|c|}{ Low } \\
\hline & Coefficient & Sig. & Coefficient & Sig. & Coefficient & Sig. & Coefficient & Sig. \\
\hline Intercept & -0.22 & 0.71 & -0.54 & 0.31 & -1.45 & 0.02 & 0.62 & 0.25 \\
\hline Past financial performance & $0.24 *$ & 0.04 & $0.43^{* *}$ & 0.01 & 0.10 & 0.43 & $0.61^{* * *}$ & 0.00 \\
\hline Firm size & -0.14 & 0.19 & 0.10 & 0.42 & 0.07 & 0.43 & -0.20 & 0.13 \\
\hline $\begin{array}{l}\text { Primary stakeholder disclosure } \\
\text { practices }\end{array}$ & $0.76^{+}$ & 0.06 & -0.03 & 0.92 & $1.00^{+}$ & 0.05 & $0.47^{+}$ & 0.08 \\
\hline $\begin{array}{l}\text { Extended stakeholder disclosure } \\
\text { practices }\end{array}$ & $1.15^{* *}$ & 0.01 & 0.53 & 0.26 & $1.30 * *$ & 0.02 & $0.88^{+}$ & 0.05 \\
\hline p-value & \multicolumn{2}{|l|}{0.01} & \multicolumn{2}{|l|}{0.07} & \multicolumn{2}{|l|}{0.05} & \multicolumn{2}{|c|}{0.00} \\
\hline Adjusted $\mathrm{R}^{2}$ & \multicolumn{2}{|l|}{0.38} & \multicolumn{2}{|l|}{0.25} & \multicolumn{2}{|c|}{0.25} & \multicolumn{2}{|c|}{0.53} \\
\hline \multicolumn{9}{|c|}{${ }^{+} \mathrm{p}<.10 * \mathrm{p}<0.05, * * \mathrm{p}<0.01, * * * \mathrm{p}<0.001$} \\
\hline \multicolumn{9}{|c|}{ Table 8: Regression models testing hypothesis $3 b$ (environmental performance) } \\
\hline & \multicolumn{4}{|c|}{ Internal GSCM practices } & \multicolumn{4}{|c|}{ External GSCM practices } \\
\hline & \multicolumn{2}{|c|}{ High } & \multicolumn{2}{|l|}{ Low } & \multicolumn{2}{|c|}{ High } & \multicolumn{2}{|c|}{ Low } \\
\hline & Coefficient & Sig. & Coefficient & Sig. & Coefficient & Sig. & Coefficient & Sig. \\
\hline Intercept & $4.14^{* * *}$ & 0.00 & $2.78 * * *$ & 0.00 & $3.29 * * *$ & 0.00 & $3.21 * * *$ & 0.00 \\
\hline Past financial performance & -0.16 & 0.43 & -0.02 & 0.58 & 0.01 & 0.66 & -0.04 & 0.19 \\
\hline Firm size & -0.12 & 0.19 & 0.11 & 0.40 & -0.09 & 0.32 & 0.07 & 0.64 \\
\hline $\begin{array}{l}\text { Primary stakeholder disclosure } \\
\text { practices }\end{array}$ & 0.18 & 0.59 & 0.01 & 0.97 & 0.59 & 0.12 & 0.04 & 0.90 \\
\hline $\begin{array}{l}\text { Extended stakeholder disclosure } \\
\text { practices }\end{array}$ & 0.32 & 0.40 & -0.16 & 0.76 & $0.72^{+}$ & 0.08 & -0.14 & 0.82 \\
\hline p-value & \multirow{2}{*}{\multicolumn{2}{|c|}{$\begin{array}{r}0.65 \\
-0.04\end{array}$}} & \multicolumn{2}{|l|}{0.89} & \multicolumn{2}{|c|}{0.49} & \multicolumn{2}{|c|}{0.73} \\
\hline Adjusted $\mathrm{R}^{2}$ & & & \multicolumn{2}{|l|}{-0.09} & \multicolumn{2}{|c|}{-0.01} & \multicolumn{2}{|c|}{-0.07} \\
\hline
\end{tabular}

${ }^{+} \mathrm{p}<.10{ }^{*} \mathrm{p}<0.05,{ }^{* *} \mathrm{p}<0.01,{ }^{* * *} \mathrm{p}<0.001$.

The results related to all tested hypotheses are summarized in Table 9, showing the impact of inclusive environmental disclosure practices on financial performance but not on environmental 
performance, and the moderation role of GSCM practices on the disclosure-financial performance relationship.

Table 9: Summary of hypotheses testing

\begin{tabular}{|c|c|c|c|c|}
\hline & \multicolumn{2}{|l|}{ Financial performance } & \multicolumn{2}{|l|}{ Environmental performance } \\
\hline Direct effects & & & & \\
\hline $\begin{array}{l}\text { Primary stakeholder } \\
\text { disclosure practices } \\
\text { (PSD) } \rightarrow \text { outcome } \\
\text { variable }\end{array}$ & $\begin{array}{l}\text { Not sign. } \\
\text { (Coeff. }=0.23 \text { ) }\end{array}$ & & Not sign. & \\
\hline \multirow{2}{*}{$\begin{array}{l}\text { Extended } \\
\text { stakeholder } \\
\text { disclosure practices } \\
\text { (ESI) } \rightarrow \text { outcome } \\
\text { variable }\end{array}$} & $\begin{array}{l}\text { Yes, sign. } \\
\text { (Coeff. }=0.52^{* *} \text { ) }\end{array}$ & & Not sign. & \\
\hline & H1: Partially supported & & H2: Not supported & \\
\hline Moderation effects & Internal GSCM practices & External GSCM practices & Internal GSCM practices & External GSCM practices \\
\hline $\begin{array}{l}\text { Primary stakeholder } \\
\text { disclosure practices } \\
\text { (PSD) } \rightarrow \text { outcome } \\
\text { variable }\end{array}$ & $\begin{array}{l}\text { Yes, PSD is only sign. in } \\
\text { high internal GSCM practices } \\
\text { (High: Coeff. }=0.76^{+} \\
\text {Low: Coeff. }=-0.03 \text { ) }\end{array}$ & $\begin{array}{l}\text { Yes, PSD is sign. higher in } \\
\text { high external GSCM } \\
\text { practices } \\
\text { (High: Coeff. }=1.00^{+} \\
\text {Low: Coeff. }=0.47^{+} \text {) }\end{array}$ & Not sign. & Not sign. \\
\hline \multirow[t]{2}{*}{$\begin{array}{l}\text { Extended } \\
\text { stakeholder } \\
\text { disclosure practices } \\
(\text { ESD) } \rightarrow \text { outcome } \\
\text { variable }\end{array}$} & $\begin{array}{l}\text { Yes, ESD is only sign. in } \\
\text { high internal GSCM practices } \\
\text { (High: Coeff. }=1.15^{* *} \\
\text { Low: Coeff. }=0.53 \text { ) }\end{array}$ & $\begin{array}{l}\text { Yes, ESD is sign. higher in } \\
\text { high external GSCM } \\
\text { practices } \\
\text { (High: Coeff. }=1.30^{* *} \\
\text { Low: Coeff. }=0.88^{+} \text {) }\end{array}$ & Not sign. & Not sign. \\
\hline & H3(a): Supported & & H3(b): Not supported & \\
\hline
\end{tabular}




\section{Discussion}

\subsection{Overview and contributions}

Environmental disclosure practices have been increasingly adopted by organizations and the number and variety of stakeholders addressed have been increasing. Previous empirical research has mainly investigated the reasons and drivers of inclusive environmental disclosure practices adoption. The present research contributes to the more recent research streams examining the impact of such practices on financial and environmental performance by analyzing inclusive environmental disclosure practices in relation to different degree and variety of stakeholders addressed and green organizational practices (i.e., GSCM) adopted.

We addressed the impact of inclusive environmental disclosure practices in relation to financial and environmental performance because previous literature proposes that disclosure practices can improve a firm's reputation and financial performance (Zhang et al., 2014) and be used to engage in a dialogue with stakeholders to improve sustainability performance (Brown, 2000). Thus, we have determined financial performance and environmental performance as outcomes variables to investigate the effectiveness of inclusive environmental disclosure practices.

Specifically, Hypothesis 1 addressed the impact of inclusive environmental disclosure practices on financial performance positing a positive relationship, in line with previous studies suggesting a positive impact through better stakeholder management, increased firm reputation and through a differentiation effect (Cerin, 2002; Hart, 1995). However, the level of inclusivity of the disclosure practices might impact their effectiveness on financial performance achievement (Zhang et al., 2016). Accordingly, we have found that firms in the analyzed sample implement environmental disclosure practices to different extents: A group of firms does not disclose environmental information with stakeholders (or do it at a low extent); a group of firms discloses 
information to a medium extent mainly with primary stakeholders (i.e., suppliers, distributors, customers and final consumers, shareholders, employees and unions, and the local community); and a group of firms highly disclose environmental information to a broader group of stakeholders including secondary stakeholders (i.e., industrial associations and NGOs, mass media, regulatory institutions, banks, scientific community and research institutions) in addition to primary stakeholders. Linking these groups to firm performance, our results provide partial support for Hypothesis 1 , meaning that a certain degree of inclusive environmental disclosure practices with stakeholders was positively related to financial performance. Specifically, a greater level of inclusiveness (i.e., higher extent and more variety of stakeholder addressed) has a positive effect on financial performance. Accordingly, the literature suggests that organizations disclose environmental information to different stakeholder groups. It is debated whether the variety of addressed stakeholders may affect the effectiveness of such practices given that different stakeholders may have different needs and expectations (Reed, 2008; Gualandris et al., 2016). Overall results indicate that inclusive environmental disclosure practices affect financial performance and specifically that higher levels of inclusive environmental disclosure practices have higher positive impacts on financial performance than not disclosing environmental information or disclosing information only to primary stakeholders. This may be due to the fact that organizations are currently under scrutiny of different sets of stakeholder, especially secondary stakeholders (e.g., NGOs and mass media (Hendry, 2005; Laasonen, 2010)). Communication about a firm's environmental performance has an impact on the reputation perceived by stakeholders, especially the farer from the firm, affecting the image of the firm. Thus, inclusive environmental disclosure practices may be more related to the legitimacy of the firm toward secondary stakeholders rather than aiming to build trust with primary stakeholders. 
Hypothesis 2 posited that inclusive environmental disclosure practices have a positive impact on the environmental performance. This hypothesis was included to situate the results of the present research with previous research suggesting that sharing information about environmental performance with stakeholders may enable a dialogue to make environmental values and priorities more explicit and included in companies' decision making to improve environmental performance (Gray and Milne, 2002). Our results do not support Hypothesis 2 since the direct impact of inclusive environmental disclosure practices on environmental performance was not significant, showing that average companies might use environmental disclosure practices to communicate to stakeholders but not necessarily to improve environmental performance.

Finally, Hypothesis 3 addressed the question of whether the absence of actual adoption of green organizational practices may determine an imbalance between what firms aim to communicate through their disclosure practices and what they actually do with potential negative impact on the credibility of the organization, and thus on outcomes achievement. In other words, this means also that when green practices are present, they may play an enabling role enhancing the positive disclosure-outcome relationship. We investigated this hypothesis focusing on GSCM practices, having them a high impact on environmental performance and being widely represented in environmental disclosure by companies, due to growing interest of stakeholders on a firm's supply chain management (Tate et al., 2010; Marshall et al., 2016). Specifically, we tested whether GSCM practices positively moderate the disclosure-outcome relationship. The results provide support for the positive moderation of GSCM practices enhancing the positive impact of inclusive environmental disclosure practices on financial performance but not on environmental performance. Specifically, when firms extensively adopt GSCM practices, the positive impact of inclusive environmental disclosure practices on financial performance is enabled. Instead, when 
GSCM practices are adopted to a limited extent, there is no positive impact of inclusive environmental disclosure practices on a firm’s financial performance. This might suggest that the monitoring role of stakeholders, through inclusive environmental disclosure practices, and the presence of green practices together enable financial performance. On the other side, if a firm discloses environmental information to stakeholders but green practices are not adopted, then the market does not legitimate the organization and no economic advantage is gained by the company.

In conclusion, we find support to the impact of inclusive environmental disclosure practices on financial performance, especially when disclosure includes secondary stakeholders and green practices are actually implemented by the firm.

Instead, inclusive environmental disclosure practices, meant as a tool to inform stakeholders about a firm's environmental performance, do not have direct impact on environmental performance. However, our results show also that the presence of GSCM practices is a crucial enabler of the positive relationship between environmental disclosure practices and financial performance. This may suggest that disclosing information may attract the attention of stakeholders toward the company reputation but the company is rewarded only if green practices are actually in place. These results might be interpreted building on the high disclosure strategies identified by Marshall et al. (2016). They propose that in case of high disclosure and high supply chain assessment and management, a firm's capabilities are developed and stakeholders are satisfied. Our results show that in line with this case when a firm implement inclusive environmental disclosure practices together with green SCM practice, that firm's financial performance will also improve. Instead, in presence of high disclosure practices but low green SCM practices, stakeholders are confused and our results show that environmental disclosure will not benefit on financial performance. Therefore, we suggest that inclusive environmental 
disclosure practices with stakeholders may be a useful tool for monitoring firms sustainable behaviors, being firms rewarded only if actual green practices are adopted. However, it is not yet a tool to engage with stakeholders to improve environmental performance. In case in the long term environmental performance does not improve, it might be that the positive relationship between disclosure practices and financial performance boosted by green practices might also disappear or become negative.

Nevertheless, the results regarding the not significant impact of disclosure practices on environmental performance may be limited by what was not measured in relation to environmental disclosure. Specifically, we did measure the extent to which information was disclosed to different sets of stakeholders but we did not measure if information sharing was done one-way or bidirectionally or the scope of the content of disclosure practices. Accordingly, recent studies suggest that to enable a real dialogue with stakeholders a bi-directional communication is needed instead of one-way information provision (Bandell, 2003; Laasonen, 2010).

Noting this limitation, the results have implications for research and practice. By focusing on the empirical test of the links between environmental disclosure practices and GSCM practices and performance, our analysis provides two main implications on future research. First, this study contributes toward the clarification of the role of inclusivity in relation to the variety of addressed stakeholders. Specifically, we empirically show that in relation to financial performance, the broader the set of addressed stakeholders addressed through environmental disclosure practices the higher the impacts. However, the complexity of addressing multiple stakeholder needs may arise in relation to environmental -and social — aspects making more complex the dialogue around such issues and their environmental -and social— performance improvement. Thus, we provide empirical support to the case for further investigation of inclusivity in environmental disclosure 
practices and suggest to develop more complex measures taking into account the type of stakeholder involvement and the context of disclosure practices.

Second, we contribute to the discussion around the impacts of inclusive environmental disclosure practices currently in place in the accounting and the supply chain management literatures. We show that these relationships are far than simple. Accordingly, we empirically show the role of green organizational practices (i.e., GSCM) to enable the link between inclusive environmental disclosure practices and organizational outcomes. Only recently, the accounting and supply chain management literatures started to integrate the discussion around environmental management (e.g., Gualandris et al., 2015; Marshall et al., 2016). Our results show that environmental disclosure practices do not serve alone as legitimation tool but it needs to be accompanied with green organizational practices adoption; if not, practices to sharing environmental information with stakeholders in absence of sustainable practices will send confusing massages to stakeholders (Marshall et al., 2016).

Concerning contributions for practice, we show to practitioners that more inclusive environmental disclosure practices may positively impact on financial performance only if actual green practices are adopted, thus it cannot just be used to reputational issues if no actual action is taken. Three main managerial implications on environmental disclosure practices adoption can be derived from this: First, firms should identify the stakeholder types to address and do not limit disclosure practices to primary stakeholders. Second, they should communicate environmental information when there are clear green practices in place to avoid confusing messages to stakeholders, which will not reward the firm with better financial performance. Third, this can be done after assessing and developing green capabilities along supply chains through GSCM. 
On the other side, on average firms inclusive environmental disclosure practices are not shown to be positively related to environmental performance per se. Therefore to improve environmental performance, managers might need to not limit environmental disclosure practices to communicate environmental performance to stakeholders but use them to establish a real dialogue with stakeholders. Also, regulators may play a role to ensure balanced reporting and assuring the rights of stakeholder information and involvement acting a monitoring role on the information disclosed.

\subsection{Conclusion and directions for future research}

In sum, this research shows that inclusive environmental disclosure practices matter in firm outcomes achievement. Specifically, we illustrate the role of environmental disclosure practices showing that the higher the variety of addressed stakeholders the higher the outcomes for the firm. However, most importantly we showed that such positive link is enabled only at the presence of actual green organizational practices, such as GSCM. When such organizational practices are lacking inclusive environmental disclosure practices are not payed off. The research makes valuable contributions showing that on average current environmental disclosure practices impact on financial performance but not on environmental performance. However, they seem to be a powerful monitoring tool such that the society praises disclosing companies only when actual green practices are adopted. Though, to build a dialogue with stakeholders to jointly contribute to environmental performance improvement more sophisticated forms of inclusive environmental disclosure practices may be needed and regulators may have to play a role in establishing such dialogue. 
The limitations of this study provide avenues for further research. First, the results of the study might be enriched by a finer grained analysis of stakeholder inclusivity. In this study, we made a distinction in terms of variety of stakeholders addressed but no distinction was made in relation to the nature of the information sharing process and the content of information disclosed. Future research may investigate whether one-way or bi-directional inclusive environmental disclosure practices have different roles in shaping an effective dialogue with stakeholders to improve corporate sustainability performance. Another aspect to take into consideration may be the coverage of information disclosed. Different environmental aspects may be considered ranging from pollution emission and resource consumption to more proactive aspects such as recycling or new business model deployment. Future research should include these attributes regarding stakeholder inclusivity to shed light on the possible different impact of different disclosure models.

In addition, all items related to inclusive environmental disclosure practices are self-reported from a single respondent so future research would be well served to collect this information also through secondary sources, for example measuring the efforts of organizations to share information with stakeholders through analyzing sustainability reports or company web-sites.

Although the study sheds light on a variety of issues surrounding inclusive environmental disclosure practices and firm outcomes and provide empirical support of the roles of stakeholder inclusivity and green practices in understanding such relationship, it would also be beneficial to test these relationships among different industries. We followed the approach suggested by Dawkins and Fraas (2011), to consider a single high-impact industry to tease out within-sector differences. However, there may be considerable differences in environmental disclosure practices among industries that have a high impact on the environment and those that have a low impact on 
the environment and, thus, different inclusive environmental disclosure approaches and impacts may be shown.

\section{References}

Al-Tuwaijri, S., Christensen, T. and Hughes, K. (2004), “The Relations Among Environmental Disclosure, Environmental Performance, and Economic Performance: A Simultaneous Equations Approach”, Accounting, Organizations \& Society, Vol. 29 No. 5/6, pp. 447-465.

Armitage, S. and Marston, C. (2008), “Corporate disclosure, cost of capital and reputation: evidence from finance directors”, British Accounting Review, Vol. 40 No. 4, pp. 314-336.

Ball A., Owen D., Gray R. (2000), "External transparency or internal capture? The role of thirdparty statements in adding value to corporate environmental reports”, Business Strategy and the Environment, Vol. 9, pp. 1-23.

Bendell, J. (2003), “Talking for change? Reflections on effective stakeholder dialogue”, in Andriof, J., Waddock, S., Rahman, S. and Husted, B. (Eds), Unfolding Stakeholder Thinking, Vol II: Relationships, Communication, Reporting and Performance, Greenleaf, Sheffield.

Bollen, K. (1989), Structural Equations with Latent Variables, John Wiley \& Sons, New York. Boyce, G. (2000), “Public discourse and decision making: Exploring possibilities for financial, social and environmental accounting”, Accounting, Auditing \& Accountability Journal, Vol. 13 No. 1, pp. $27-64$.

Brow, J. and Fraser, M. (2006), “Approaches and Perspectives in Social and Environmental Accounting: an Overview of the Conceptual Landscape”, Business Strategy and the Environment, Vol. 15, pp. 103-117.

Brown, J. (2000). “Competing ideologies in the accounting and industrial relations environment”, British Accounting Review, Vol. 32, pp. 43-75.

Burritt R. and Welch S. (1997), “Australian commonwealth entities: an analysis of their environmental disclosures”, Abacus, Vol. 33 No. 1, 1-19.

Byrne, B.M. (2006), Structural Equation Modelling with EQS: Basic Concepts, Applications, and Programming, Lawrence Erlbaum Associates, Mahwah, NJ. 
Carter, C. and Rogers, D. (2008), “A framework of sustainable supply chain management: Moving toward new theory”, International Journal of Physical Distribution and Logistics Management, Vol. 38 No. 5, pp. 360-387.

Cerin, P. (2002), “Communication in corporate environmental reports”, Corporate Social Responsibility and Environmental Management, Vol. 9 No. 1, pp. 46-65

Clarkson, P., Li, Y., Richardson, G., Vasvari, F. (2008), "Revisiting the relation between environmental performance and environmental disclosure: an empirical analysis”, Accounting Organization Society, Vol. 33, pp. 303-327.

Cormier, D., Ledoux, M., Magnan, M. (2009), “The use of web sites as a disclosure platform for corporate performance”, International Journal of Accounting Information Systems, Vol. 10 No. 1, pp. 1-24.

Cormier, D., Ledoux, M., Magnan, M. (2011), “The informational contribution of social and environmental disclosures for investors”, Management Decisions, Vol. 49 No. 8, pp. 12761304.

Dawkins, C. and Fraas, J. (2011). "Beyond Acclamations and Excuses: Environmental Performance, Voluntary Environmental Disclosure and the Role of Visibility”, Journal of Business Ethics, Vol. 99, pp. 383-397.

Deegan, C., Cooper, B. and Shelly, M. (2006), “An investigation of TBL report assurance statements: UK and European evidence”, Management Auditing Journal, Vol. 21, pp. 329_ 371.

Esrock, S. and Leichty, G. (1998), “Social responsibility and corporate web pages: Selfpresentation or agenda-setting?”, Public Relations Review, Vol. 24 No. 3, pp. 305-319.

Flynn, B.B., Huo, B., Zhao, X., 2010. “The impact of supply chain integration on performance: a contingency and configuration approach”, Journal of Operations Management, Vol. 28, pp. ,58-71.

Fombrun, C. and Shanley, M. (1990), "What's in a Name? Reputation Building and Corporate Strategy”, Academy of management Journal, Vol. 33 No. 2, pp. 233-258.

Fornell, C. and Larcker, D.F. (1981), “Evaluating structural equation models with unobservable variables and measurement error”, Journal of Marketing Research, Vol. 18 No.1, pp. 39-50.

Freeman, R. (1984), Strategic management: A stakeholder approach, Pitman, Boston. 
Gelb, D. and Strawser, J. (2001), “Corporate Social Responsibility and Financial Disclosures: An Alternative Explanation for Increased Disclosure”, Journal of Business Ethics, Vol. 33, pp. $1-13$.

Gimenez, C. and Sierra, V. (2013), "Sustainable supply chains: Governance mechanisms to greening suppliers”, Journal of Business Ethics, Vol. 116, pp. 189-203.

Gimenez, C., Sierra, V. and Rodon, J. (2012), "Sustainable operations: Their impact on the triple bottom line”, International Journal of Production Economics, Vol. 140 No.1, pp. 149-159. Global Reporting Initiative (2013), Sustainability Reporting Guidelines, Stitching Global. Reporting Initiative (GRI), Amsterdam, The Netherlands, http://www.globalreporting.org

Gray, R. H. (2000), “Current developments and trends in social and environmental auditing, reporting and attestation: A review and comment”, International Journal of Auditing, Vol. 4 No. 3, pp. 247-268.

Gray, R. and Milne, M. (2002), “Sustainability reporting: Who’s kidding who?”, Chartered Accountants Journal of New Zealand, Vol. 81 No. 6, pp. 66-70.

Gray, R., Kouhy, R. and Lavers, S. (1995), “Corporate Social and Environmental Reporting: A Review of the Literature and a Longitudinal Study of UK Disclosure”, Accounting, Auditing \& Accountability Journal, Vol. 8 No. 2, pp. 47-77.

Green, K., Zelbst, P., Meacham, J. and Bhadauria, V. (2012) "Green supply chain management practices: impact on performance", Supply Chain Management: An International Journal, Vol. 17 No. 3, pp. 290- 05.

Gualandris, J., Klassen, R., Vachon, S. and Kalchschmidt, M. (2016), “Sustainable evaluation and verification in supply chains: Aligning and leveraging accountability to stakeholders”, Journal of Operations Management, Vol. 38, pp. 1-13.

Hart, S. (1995), “A natural resource based view of the firm”, Academy of Management Review, Vol. 20 No. 4, pp. 986-1014.

Hendry, J. (2005), “Stakeholder Influence Strategies: An Empirical Exploration”, Journal of Business Ethics, Vol. 61, pp. 79-91.

Hu, L. and Bentler, P. M. (1999), “Cutoff criteria for fit indexes in covariance structure analysis: conventional criteria versus new alternatives”, Structural Equation Modeling, Vol. 6 No. 1, pp. 1-55.

Keil, M., Tan, B. C. Y., Wei, K.-K., Saarinen, T., Tuunainen, V., and Wassenaar, A. (2000), “A 
cross-cultural study on escalation of commitment behavior in software projects", Management Information Systems Quarterly, Vol. 24 No. 2, pp. 299-325.

Kelly, M. (2001), The Divine Right of Capital. Berrett-Koehler: San Francisco.

Khan, M., Serafeim, G. and Yoon, A. (2016), “Corporate Sustainability: First Evidence on Materiality”, The Accounting Review, Vol. 91, No. 6, pp. 1697-1724

Klassen, R. and Whybark, D. (1999), “The impact of environmental technologies on manufacturing performance”, Academy of Management Journal, Vol. 42, pp. 599-615.

Kleindorfer, P. and Saad, G. (2005), “Managing disruption risks in supply chains”, Production and Operations Management, Vol. 14, pp. 53-68.

Kolk, A. (2003), “Trends in sustainability reporting by the Fortune Global 25”, Business Strategy and the Environment, Vol. 12 No. 5, pp. 279-291.

Krause, D., Vachon, S. and Klassen, R. (2009), “Special topic forum on sustainable supply chain management: Introduction and reflections on the role of purchasing management”, Journal of Supply Chain Management, Vol. 45 No. 4, pp. 18-24.

Laasonen, S. (2010), "The role of stakeholder dialogue: NGOs and foreign direct investments", Corporate Governance: The international journal of business in society, Vol. 10 No. 4, pp. $527-537$.

Manetti, G. and Toccafondi, M. (2011), “The Role of Stakeholders in Sustainability Reporting Assurance”, Journal of Business Ethics, Vol. 107, pp. 363-377.

Marshall, D., McCarthy, L., McGrath, P. and Harrigan, F. (2016), "What's Your Strategy for Supply Chain Disclosure?”, MIT Sloan Management Review, Winter 2016, pp. 37-45.

Morhardt, J., Baird, S. and Freeman, K. (2002), "Scoring corporate environmental and sustainability reports using GRI 2000, ISO 14031 and other criteria”, Corporate Social Responsibility and Environmental Management, Vol. 9 No. 4, pp. 215-233.

New, S. (2015), "Modern slavery and the supply chain: the limits of corporate social responsibility?”, Supply Chain Management: An International Journal, Vol. 20 No. 6, pp. 697-707.

Owen, D., Swift, T. and Hunt K. (2001), “Questioning the role of stakeholder engagement in social and ethical accounting, auditing and reporting”, Accounting Forum, Vol. 25 No. 3, pp. 264-282. 
Owen, D., Swift, T., Humphrey, C. and Bowerman, M. (2000), “The new social audits: accountability, managerial capture or the agenda of social champions?” European Accounting Review, Vol. 9 No. 1, pp. 81-98.

Pagell, M. and Wu, Z. (2009), "Building a more complete theory of sustainable supply chain management using case studies of 10 exemplars”, Journal of Supply Chain Management, Vol. 45, pp. 37-56.

Patten, D. (2002). “The Relation Between Environmental Performance and Environmental Disclosure: A Research Note”, Accounting, Organizations \& Society, Vol. 27 No. 8, pp. 763-773.

Plumlee, M., Brown, D.,Hayes, R. and Marshall, S. (2015), "Voluntary environmental disclosure quality and firm value: Further evidence”, Journal of Accounting Public Policy, Vol. 34, pp. 336-361.

Porter, M. and van der Linde, C. (1995), “Green and competitive: Ending the stalemate”, Harvard Business Review, Vol. 73 No. 5, pp. 120-134.

Reed, M. (2008), “Stakeholder participation for environmental management: A literature review”, Biological Conservation, Vol. 141, pp. 2417-2431.

Qiu, Y., Shaukat, A. and Tharyan, R. (2016), "Environmental and social disclosures: Link with corporate financial performance”, The British Accounting Review, Vol. 48, pp. 102-116.

Russo, M. and Fouts, P. (1997), “A resource-based perspective on corporate environmental performance and profitability”, Academy of Management Journal, Vol. 40 No. 3, pp. 534559.

Sarkis, J. (2012), “A boundaries and flows perspective of green supply chain management”, Supply Chain Management: An International Journal, Vol. 17 No. 2, pp. 202-216.

Sarkis, L. and Rasheed, A. (1995), “Greening the manufacturing function•, Business Horizon, Vol. 38 No. 5, pp. 17-27.

Solomon, A. and Lewis, L. (2002), "Incentives and disincentives for corporate environmental disclosure”, Business Strategy and the Environment, Vol. 11 No. 3, pp. 154-169.

Springett, D. (2003). "Business conceptions of sustainable development: a perspective from critical theory”, Business Strategy and the Environment, Vol. 12, pp. 71-86.

Stock, J. and Boyer, S. (2009), “Developing a consensus definition of supply chain management: A qualitative study”, International Journal of Physical Distribution \& Logistics 
Management, Vol. 39 No. 8, pp. 690-711

Svendsen, A. (1998), The Stakeholder Strategy: Profiting from Collaborative Business Relationships, Berrett-Koehler Publishers.

Tate, W., Ellram, L. and Kirchoff, J. (2010). "Corporate social responsibility reports: a thematic analysis related to supply chain management”, Journal of supply chain management, Vol. 46 No. 1, pp. 19-44.

Tinker, T., Neimark, M. and Lehman, C. (1991),"Falling down the Hole in the Middle of the Road: Political Quietism in Corporate Social Reporting", Accounting, Auditing \& Accountability Journal, Vol. 4 No. 2, pp. 28-61.

Vachon, S. (2007), “Green supply chain practices and the selection of environmental technologies”, International Journal of Production Research, Vol. 45 No. 18-19, pp. 4357-4379.

Vickery, S., Jayaram, J., Droge, C. and Calantone, R. (2003), “The effects of an integrative supply chain strategy on customer service and financial performance: an analysis of direct versus indirect relationships”, Journal of Operations Management, Vol. 21 No. 5, pp. 523-539.

Walker, P. (2002), "Understanding accountability: theoretical models and their implications for social service organizations”, Social Policy and Administration, Vol. 36 No. 1, pp. 62-75.

Walls, J., Berrone, P. and Phan, P. (2012), “Corporate governance and environmental performance: Is there really a link?” Strategic Management Journal, Vol. 33, pp. 885-913.

Wilmshurst, T. and Frost, G. (2000), “Corporate environmental reporting: A test of legitimacy theory", Accounting, Auditing \& Accountability Journal, Vol. 13 No. 1, pp.10-26.

Wolf, J. (2014), “The relationship between sustainable supply chain management, stakeholder pressure and corporate sustainability performance”, Journal of Business Ethics, Vol. 119, pp. 317-328.

Zhu, Q., Sarkis, J., \& Geng, Y. (2005), “Green supply chain management in China: Pressures, programs and performance”, International Journal of Operations \& Production Management, Vol. 25 No. 5, pp. 449-468.

Zhu, Q., Sarkis, J. and Lai, K.H. (2012), "Examining the effects of green supply chain management practices and their mediations on performance improvements", International Journal of Production Research, Vol. 50 No. 5, pp. 1377-1394. 
Zsidisin, G. and Siferd, S. (2001), "Environmental purchasing: A framework for theory development”, European Journal of Purchasing and Supply Management, Vol. 7 No. 1, pp. $61-73$. 